\title{
Decline of materials intensiveness
}

\section{The US pulp and paper industry}

\author{
Marc Ross and Arthur H. Purcell
}

\begin{abstract}
Despite the USA's image as a throwaway society, materials consumption per real GNP is declining, and has been for several years. Materials conservation practices in industry and a shift towards a service economy are two important factors in the decline of material intensiveness. The authors document this resource trend for the paper Industry and conclude that an important cause of material intensiveness decline for this industry is the concept of product maturity. Future policy options are also analysed.
\end{abstract}

Marc Ross is with the Energy Productivity Center of the Mellon Institute and the Physics Department, University of Michigan, Ann Arbor, MI 48109, USA; Arthur Purcell is with Technical Information Project, Inc, 1346 Connecticut Avenue NW, Suite 217, Washington, DC 20036, USA.

The authors thank the staff at the American Paper Institute for generously making information available. Responsibility for the analysis and conclusions is entirely the authors'.

'Mainly chemicals, steel, petroleum refining, paper, food, non-ferrous metals, cement, brick and glass manufacturing.

${ }^{2}$ Marc Ross and Robert Williams, Our Energy: Regaining Control, McGraw Hill, New York, 1981.
The flow of materials and the flow of energy in the US economy are intimately related. About $85 \%$ of all energy used in manufacturing, or $25 \%$ of total US energy consumption, goes to basic materials ${ }^{1}$ processing. Changes in energy flows will clearly affect material flows. Similarly, changes in material flows will have an impact upon the flow of energy in the US system.

Over the next twenty years there will be innumerable materials-energy interactions that will affect their relative flows. Prices, energy and materials availability, development of alternative energy sources, changes in consumer demands for materials, new materials technologics, and government regulation are some of the major factors that will determine the nature of these interactions.

\section{The determination of material trends}

Webster's Dictionary defines trend as 'a general direction taken'. In the case of materials trends, we have endeavoured to characterize these 'general directions' and determine whether a clear flow pattern emerges. There are three basic determinants of dircctions: demand changes, resource and technology changes, and regulations and fiscal policy.

Consumer demand is clearly a central determinant of materials trends. As a nation the USA is demanding less materials per real unit of GNP now than it has in the past (Figure 1). The long-term trend from industrial products toward services has been supplemented by a downturn in the 1970s in the use of materials per unit of industrial production (Figure 2). Thus Figure 1 shows that industrial value added has been declining with respect to GNP for at least three decades. In Figure 2 the solid lines are regression fits for 1969-1978; they show that for major materials the consumption by weight was declining with respect to real industrial value added for all the materials shown except chemicals. The three major materials by weight - lumber, steel and cement - were declining rapidly per deflated dollar of industrial value added during this period. Chemicals were increasing only slowly. ${ }^{2}$

This decline in materials use per dollar is associated with the stiff 
Decline of materials intensiveness

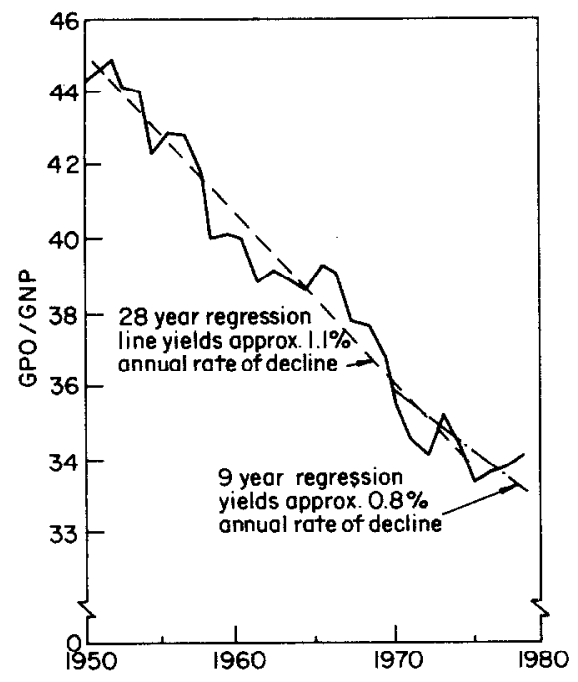

Figure 1. Ratio of industrial value added (GPO) to GNP, 1950-1978 (in current dollars).

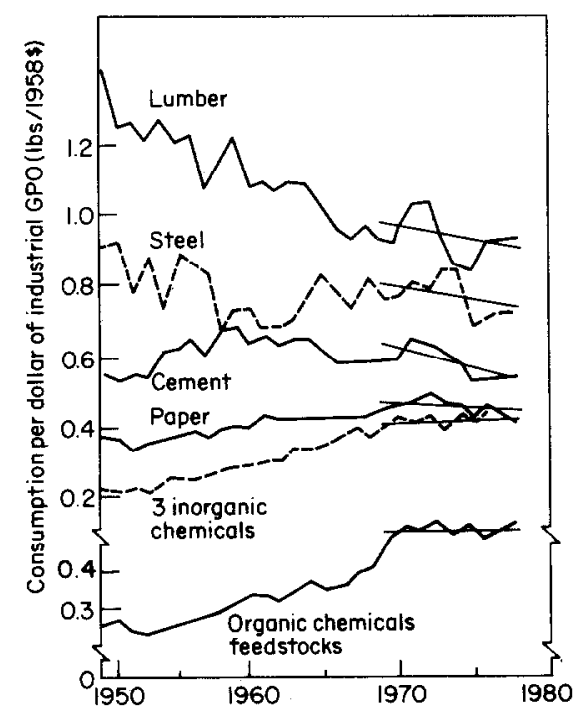

Figure 2. Consumption of basic materials by industry per unit of industrial value added, 1950-1978.

${ }^{3}$ American Can, the nation's largest maker of steel cans, has been developing a twopiece 'drawn and ironed' can which it claims will be no more energy-intensive (and presumably no more expensive) than a 10-trip returnable glass bottle of similar volume. If American Can is successful, this will be an important example of technological innovation that can effectively reshape a materials trend brought on by regulation.

${ }^{4}$ The recent Supreme Court ruling in the National Crushed Stone Association v EPA made it clear that industries which cannot meet water standards cannot expect indefinite variances, even if this means going out of business. competition which consumer goods experience from labour- and knowledge-intensive services such as health, information and entertainment; with saturation in old consumer goods applications such as large home appliances and with refinement in the use of materials, eg the long-term shift of the steel industry from heavy rails (the dominant nineteenth-century product) to thin sheet steel for automobiles (the dominant late-twentieth-century product).

Technology is playing a critical role in materials flows. Demand substitutions are occurring as the result of the creation of less expensive or higher performance products made from new materials such as plastics. New manufacturing technology is also important. For example, microelectronics technology has made possible production of higher-tolerance, lower-waste materials product manufacturing systems. This has, in turn, affected demand for these products.

Resource constraints may also influence materials flows. Technology is, however, often able to adapt to resource constraints. Thus taconite pellets successfully replaced the declining hemative ores in Minnesota. As far as energy resources are concerned, it seems likely that energy efficiency improvements and fuel shifts will help control the cost of many materials and keep them competitive. In the case of paper, for instance, efficiency improvements and an increasing use of wood wastes and byproducts to meet energy needs is helping the industry to keep down the energy price increases it passes on.

Container deposit legislation is an example of a potentially important area of regulation which favours certain material flows over others. While consumers have supposedly demanded 'throwaway' beverage containers, several state legislatures have acted to control 'throwaways' by requiring deposits on beer and soft drink containers. National deposit legislation is also a possibility.

Mandatory deposits have favoured glass beverage containers because they can be directly re-used after washing and labelling. It has also, however, stimulated steel and aluminium container makers to establish more recycling centres and to push recycling technologies. ${ }^{3}$

Environmental regulations and land use regulations are two very important areas which may have profound impacts on materials flows. No major material industry has ceased functioning due to environmental regulations, and adequate data are not available to determine the extent to which one material has been favoured over another due to the economic costs of pollution control. It is conceivable, though, that in the next twenty years some materials, or grades of materials, may gain or lose market shares because of pollution control costs. ${ }^{4}$

Land use policy, considered by many analysts as one of the crucial federal decision areas in the next decade, may have significant impacts on the supply of virgin materials and thus directly affect both the magnitudes of materials flows and the relative flows of virgin and recycled materials.

The mix of materials in the aggregate demand will be determined by the synergism of countless individual demand decisions, technological events, and regulations and fiscal policies that will affect these phenomena. This synergism can result in a simple materials substitution - eg plastic instcad of paper bags - or it can result in the replacement of a materials-intensive system with one which utilizes relatively little material. Using video display equipment instead of buying newspapers, books, and magazines; conducting large meetings by telephone and computer display instead of face to face (thereby reducing the need to 


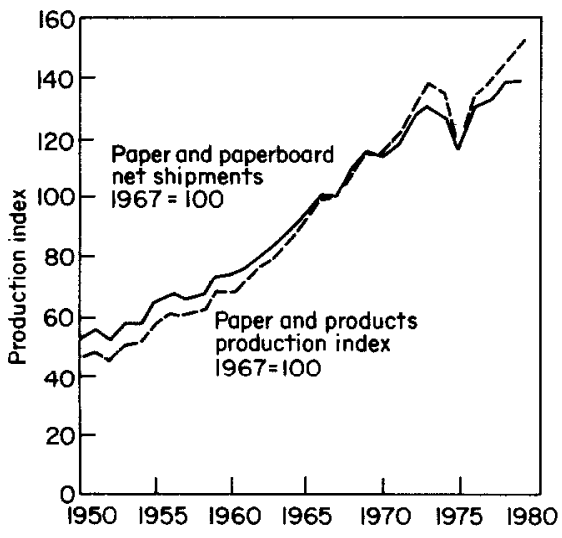

Figure 3. Physical and economic indices of paper production.

Table 1a. Growth rates for the paper industrya (\% per annum).

\begin{tabular}{lll}
\hline & $\begin{array}{l}\text { Paper and board } \\
\text { (tons/year API) }\end{array}$ & $\begin{array}{l}\text { SIC 26 } \\
\text { FRB index }\end{array}$ \\
$1969-1979$ & 1.8 & 2.4 \\
$1960-1979$ & 3.4 & 4.1 \\
$1950-1979$ & 3.7 & 4.5 \\
\hline
\end{tabular}

aRegression analysis of annual data.

Table 1b. Construction of the FRB index for pulp and paper.

\begin{tabular}{|c|c|c|}
\hline Time series & $\begin{array}{l}\text { FRB fixed } \\
\text { weights }\end{array}$ & $\begin{array}{l}\text { Growth rate } \\
1969-1979 \\
\text { (\% per annum) }\end{array}$ \\
\hline $\begin{array}{l}\text { Pulp and paper } \\
\text { Wood pulp } \\
\text { Paper and } \\
\text { paperboard }\end{array}$ & $\begin{array}{l}1.38 \\
0.50 \\
0.88\end{array}$ & $\begin{array}{l}1.4 \\
1.8\end{array}$ \\
\hline $\begin{array}{l}\text { Converted products } \\
\text { Printing and } \\
\text { writing papers } a\end{array}$ & $\begin{array}{l}1.83 \\
0.76\end{array}$ & 3.4 \\
\hline $\begin{array}{l}\text { Sanitary tissue } \\
\text { Shipping containers }\end{array}$ & $\begin{array}{l}0.18 \\
0.84\end{array}$ & $\begin{array}{l}1.9 \\
2.7\end{array}$ \\
\hline $\begin{array}{l}\text { Construction } \\
\text { paper and board }\end{array}$ & 0.06 & 1.4 \\
\hline Total & 3.21 & $2.4^{b}$ \\
\hline
\end{tabular}

a For simplicity two similar categories have been combined in each of these categories.

bCalculated by combining the individual growth rates shown using the weights shown.

Table 2. Decline in growth rate during the 1970 s a (\% per annum).

\begin{tabular}{ll}
\hline & Production/GNP \\
$1969-1979$ & -1.0 \\
$1960-1979$ & -0.2 \\
$1950-1979$ & 0.2 \\
\hline
\end{tabular}

aRegression analysis of annual data. build transport devices); using new high strength steels to reduce the weight (and fuel requirements) of automobiles; and increasing residential densities (thereby reducing the need for materials to build housing and transportation facilities) are four such examples.

In sum, the interaction of demand, technology, and regulation and fiscal policy will determine materials trends.

\section{Paper}

As a voracious consumer of paper, the USA has developed a high reliance on this material for communication, packaging, construction, shipping, hygiene and other applications. The 'information explosion' that has been facilitated by large-scale computer use makes printing paper an exception to the decline of materials mentioned above and puts its growth well ahead of other paper end-uses. Paradoxically, the same technology could eventually bring on the so-called 'paperless office', in which electronic display and computer storage replace countless papers and books, thus posing a severe threat to what is now the most dynamic part of the paper industry. Meanwhile, the shipping container and box are, as we shall see, mature products. That is, the demand for them is no longer growing more rapidly than the potential applications. Indeed, boxboard (see Appendix) for food packaging applications is declining with respect to food packaging activity because of competition from plastics. On the basis of analysis of trends such as these, we project a gradual decline in the use of paper products (tonnage) with respect to real GNP. This is a very different projection than is generally provided by macroeconomists, who typically predict that domestic consumption of paper products will grow with respect to GNP. The reason for this apparent discrepancy will be carefully spelled out.

Another issue is the mix of materials inputs to the paper industry. The mix of virgin and recycled fibre inputs has the potential for a much larger fraction of recycled fibre than is currently the practice. A host of policy considerations will be strongly influential in determining the mix. The recent emphasis on energy recovery from wastes, with resultant constraints on recycling such as flow control ordinance, flies in the face of this recycling potential.

\section{Consumption and production}

\section{Physical measures $\mathrm{v}$ economic measures}

Trends in materials flows can be measured in both physical (tons/year) and economic (some measure of economic value/year) terms. The Federal Reserve Board (FRB) indices are partly economic measures, while industry association figures are provided in physical units. Analysis readily shows that trends are significantly different when measured physically and economically (Figure 3 ). If exponential growth curves are fitted to domestic production in tons and to the FRB index for the Paper and Allied Products Industry (SIC 26), the results shown in Table 1a are obtained for growth rates in percent per annum. On average, the FRB index grows $0.7 \%$ faster than physical production.

The reason for this difference, even though the FRB index is partly based on physical measures, is straightforward. The FRB index is constructed by combining selected time varying production series, which are mostly physical, using fixed value-added weights as shown in Table 
Decline of materials intensiveness

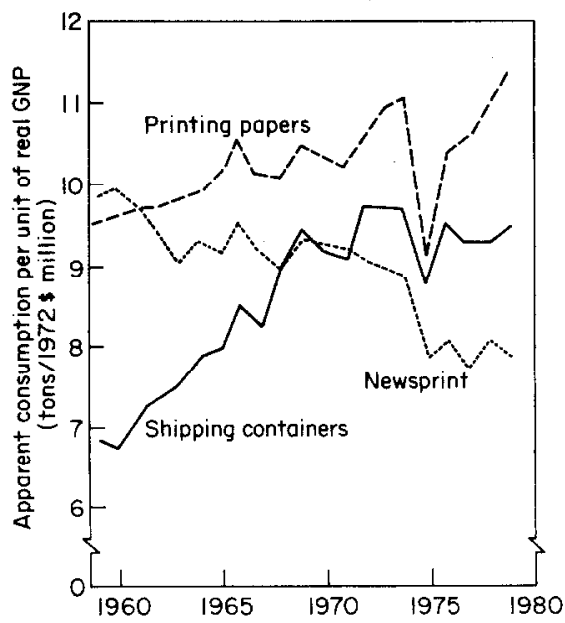

Figure 4. Apparent consumption of paper products per unit of real GNP.
Source: American Paper Institute, Statistics of Paper and Paperboard, 1980, New York, NY, Table X.

aRegression analysis of annual data.

bTo obtain absolute growth add $4.3 \%$.

CTo obtain absolute growth add $2.8 \%$.

dprimarily corrugated shipping box material: unbleached kraft linertoard plus semichemical corrugating material.

eprimarily boxboard such as for cold cereal boxes and milk cartons.

fNot including hard pressed board. 1b. Only $43 \%$ of the weight for the paper industry index is assigned to basic pulp and paper production with the rest of the weight given to converting activities (the coating, cutting and packaging of papers, the making of bags and boxes, etc.). A visit to a typical paper and pulp mill quickly reveals this structure: very few employees are in evidence in the vast wood handling, pulping, bleaching and paper-making facilities. In the relatively small facilities where the product is cut up and packaged many workers are seen. In fact, exactly one half of the weight in the FRB index for the paper industry is given to two converting activities producing paper products (exclusive of tissue) from paper and containers from paperboards. These activities are represented by the physical time series for printing and writing papers and shipping containers respectively (see Table 1b). These two product categories are the strongest growth areas in the industry. Because of the added weight these products receive in the FRB index compared to a simple physical measure the former has been growing more rapidly than the latter $(2.4-1.8=0.6 \%$ per annum more rapidly during 1969-1979 as shown in Table 1a).

One might quarrel with the FRB selection of time series to represent converting activity. For example, paper packaging and boxboard activity are both growing much less than the time series used. The essential fact, however, is that any economic index for such an industry must emphasize the downstream activities while energy analysis must be sensitive to the upstream activities. Simple adoption of an economic index is therefore inappropriate for energy analysis.

This result is important. Industrial energy requirements have been projected on the basis of trends in economic production indices of production such as FRB indices. The direct use of such an index for use in an energy analysis based on energy requirements per ton of product will result in serious errors in long-term projections. For example, a $0.7 \%$ per annum discrepancy, as in the case of paper, implies $15 \%$ discrepancy in production (and new capacity) at the end of 20 years.

\section{Trends in physical units per unit of real GNP}

Domestic production of paper and board (physical) per unit of real GNP fell in the 1970s (just as use of most other basic materials fell) (Table 2). Consumption (ie correcting production for imports and exports) also fell. Consumption and production per unit of real GNP have been fairly constant except for a drop in the mid-1970s. The major questions for

\begin{tabular}{|c|c|c|c|}
\hline & $\begin{array}{l}\text { Thousand tons per } \\
\text { billion } 1972 \$\end{array}$ & $\begin{array}{l}\text { Growtha } \\
\text { (\%/year 1959-69b) }\end{array}$ & $\begin{array}{l}\text { Growtha }^{a} \\
(\% / \text { year 1969-79C) }\end{array}$ \\
\hline $\begin{array}{l}\text { Paper } \\
\text { Newsprint } \\
\text { Printing/writing } \\
\text { Packaging \& industrial } \\
\text { Tissue } \\
\text { Subtotal }\end{array}$ & $\begin{array}{r}7.8 \\
11.4 \\
3.9 \\
3.1 \\
36.3\end{array}$ & $\begin{array}{r}-0.8 \\
0.9 \\
-1.7 \\
1.1\end{array}$ & $\begin{array}{r}-2.2 \\
0.5 \\
2.2 \\
-1.0\end{array}$ \\
\hline $\begin{array}{l}\text { Paperboard } \\
\text { Unbleached kraft and } \\
\text { semichernicald } \\
\text { Bleached kraft and } \\
\text { recyclede } \\
\text { Subtotal }\end{array}$ & $20.4^{7.8}$ & -2.1 & $\begin{array}{l}-0.2 \\
-2.6\end{array}$ \\
\hline $\begin{array}{l}\text { Construction } \\
\text { Paper and board } f\end{array}$ & 2.6 & -2.9 & -1.5 \\
\hline Total & 49.4 & -0.05 & -1.1 \\
\hline
\end{tabular}


analysis are, then: what was the reason for this drop; and will the decline be likely to continue during the rest of the century, and at what rate?

\section{Trends in apparent consumption of subproducts}

Paper and paperboard products are conveniently grouped into roughly seven categories (see Appendix). The consumption trend for printing and writing papers is strong, for tissue moderate, and for packaging and newsprint weak. Shipping containers are fairly strong and boxboard weak (Table 3).

The apparent consumption per unit of real GNP, 1959-1979, is shown in Figure 4 for certain products. The remarkable levelling off of shipping container growth after 1969 is shown. Although corrugated shipping containers are now roughly keeping pace with GNP, the most remarkable shift from the 1950s and 1960s to the 1970s is the rapid growth in shipping containers (domestic consumption per unit of real GNP) in the earlier decades, and the absence of that growth in the 1970s.

The major decline in growth of shipping containers is probably attributable to saturation in new uses of those containers. In the 1970s the shipping container to GNP ratio remained fixed. An analysis by the American Paper Institute ${ }^{5}$ showed that an index of production of packagable goods rose very slightly faster than GNP in the 1970s, while use of shipping containers fell very slightly (a total of $4 \%$ over the decade) with respect to this index. This 'mature' behaviour is in contrast to the $1950 \mathrm{~s}$ and 1960s, when new uses of shipping containers were being established. This conclusion is supported by the shift in shipping practices in the 1950s and 1960s towards protection, through the use of corrugated shipping containers, of new household appliances in transportation and sales.

The number of households grew $2.1 \%$ per annum more slowly than real GNP in the 1960s, and $0.9 \%$ per annum more slowly than GNP in the $1970 \mathrm{~s}$. So, although it is not surprising that newsprint consumption grew more slowly than GNP, the rate of growth of households does not fully explain the drop in growth of use of newsprint in the 1970s with respect to the 1960 s. ${ }^{6}$ Newsprint consumption per unit of GNP did drop because of a deliberate move to lower weight per unit area of paper. This may have had as much as a 5\% effect. However, the decline in newsprint per household over the decade was over $10 \%$. An additional reason for the decline is competition with electronic media.

${ }^{5}$ Private communication, $\mathrm{Dr} \mathrm{B}$. Slatin, American Paper Institute.

${ }^{6}$ The shape of the newsprint trend suggests that a major $(10 \%)$ adjustment took place with the 1975 recession (superimposed on a gradual long-term decline). Major adjustment in product use at a time of recession is an important mechanism for demand change.

\footnotetext{
aHouseholds/GNP for the period 1970-1978. 'bervice employees (blue collar plus 'service' employees)/GNP for the period 1970-1978 (Table 685, Statistical Abstract 1979, US Government Printing Office, Washington, DC).

CFood sales/GNP for the period 1970-1978 (Tables 1465 and 791, Statistical Abstract 1979 , US Government Printing Office, Washington, DC).

dPopulation/GNP (Table 2, Statistical Abstract 1979, US Government Printing Office, Washington, DG)

eAPI index of packagable goods (Dr B. Slatin, private communication).
}

Paper packaging and boxboard production has declined because of competition from plastics. These categories are not expected to grow with GNP because a major proportion of production is associated with grocery sales, wich grew $2.3 \%$ per annum more slowly than GNP in the 1970s. An additional 0.5 to $1 \%$ per annum decline in these categories can perhaps be attributed to substitution by plastics. An examination of the drop in retail merchandise bags (not grocery bags) and food containers suggests an

Table 4. Relation of 1969-1978 product growth rates to growth of selected indicators, all with respect to real GNP.

\begin{tabular}{lcc}
\hline & Consumption/GNP & Indicator/GNP \\
Paper & & \\
Newsprint & -2.2 & $-0.9^{\mathrm{a}}$ \\
Printing & 0.5 & $-0.3^{\mathrm{b}}$ \\
Packaging & -2.2 & $-2.3^{\mathrm{c}}$ \\
Tissue & -1.0 & $-2.0^{\mathrm{d}}$ \\
Paperboard & & \\
Container & -0.2 & $0.3^{\mathrm{e}}$ \\
Boxboard & -2.6 & $-2.3^{\mathrm{c}}$ \\
\hline
\end{tabular}


PPlastics vs Paper and Plastics vs Paperboard, Business Communications Co, Inc, Stamford, CT 06906, 1980.

${ }^{8}$ American Paper Institute, Recent Market Pressures in Plastics Packaging. New York, NY, 1980. overall loss of paper and board consumption between 1 and 2 million tons per year due to plastics substitution. This level of substitution is confirmed in detail by proprietary studies. ${ }^{7}$

Although growth in printing papers fell slightly in the 1970s, the important fact is that use of these papers continues to grow faster than GNP. A basic indicator for printing paper consumption is the number of service employees. This number grew $2.9 \%$ per annum (1970-1978), almost as fast as real GNP (growth of 3.2\% per annum 1970-1978). Clearly, printing paper consumption per service employee is growing, a trend to be discussed further below.

The apparent conclusion to be drawn is that product use was growing roughly in accordance with underlying markets in the 1970s: printing papers with service employees, shipping containers with packagable goods, packaging and boxboard with groceries, and tissues with population (Table 4). The most significant deviations from this rule appear to be printing papers, which grew almost $1 \%$ per annum faster than service employees, and newsprint use, which declined over $1 \%$ per annum with respect to households. Late-1970s trends confirm that by far the strongest element in the domestic paper market is the growth in use of printing papers, ie it is faster than indicators such as GNP or service employees. Meanwhile late-1970s trends indicate a recovery by newsprint. Perhaps it is following the number of households more closely than is indicated by 1970s data overall.

\section{Competition with plastics}

A major shift to plastics has already occurred in retail merchandise bags and food containers. This substitution could proceed significantly further. There is considerable interest on the part of some plastics firms in the USA in extending the substitution for paper, for example in the area of stand-open grocery bags. Recent price developments in the USA seem to suggest that the potential for further substitution by plastics in the USA will, however, be limited. ${ }^{8}$ The Europeans favour plastics over paper more than Americans. This may be associated with relatively high paper costs in Europe.

\section{Competition with electronic display}

As a result of the information explosion, printing paper use continues to grow even faster than GNP (or service employees). Of course the growth in communication and information, while generating growth in the use of paper, does not cause proportional growth in the use of paper. On the other hand, electronic equipment and associated procedures which actually reduce specific existing uses of paper are limited and scattered. While certain kinds of record keeping which used to involve creating extra copies can now be handled electronically, primary transactions almost

\begin{tabular}{|c|c|c|c|}
\hline Imports & & Exports & \\
\hline $\begin{array}{l}\text { Woodpulp } \\
\text { Chemical }\end{array}$ & $\begin{array}{l}4.0 \\
3.6\end{array}$ & $\begin{array}{l}\text { Woodpulp } \\
\text { Dissolving } \\
\text { Chemical }\end{array}$ & $\begin{array}{l}2.6 \\
0.8 \\
1.8\end{array}$ \\
\hline $\begin{array}{l}\text { Paper, paperboard and construction } \\
\text { Newsprint } \\
\text { Printing papers } \\
\text { Construction paper and paperboard }\end{array}$ & $\begin{array}{l}9.3 \\
7.5 \\
0.9 \\
0.6\end{array}$ & $\begin{array}{l}\text { Waste paper } \\
\text { Paper, paperboard and construction } \\
\text { Paper } \\
\text { Paperboard }\end{array}$ & $\begin{array}{l}1.6 \\
2.9 \\
0.5 \\
2.3\end{array}$ \\
\hline Total imports of paper and allied products & 13.5 & Total exports of paper and allied products & 7.7 \\
\hline
\end{tabular}


always continue to require paper. It is not even clear that possibilities such as offices equipped with personal micro-computers and computer mail services could reduce the demand for 'hard' copy. The potential impact of electronic media on the paper market is thus difficult to predict with any certainty. ${ }^{y}$

\section{Imports and exports}

The principal US imports are from Canada: chemical pulp, and paper and board based on mechanical pulp, especially newsprint. Exports go to diverse markets: with dissolving pulps for rayon and chemical pulp, and kraft linerboard for use in shipping containers, being the principal exports (Table 5).

Almost $70 \%$ of newsprint used in the USA is manufactured in Canada. Many firms are major paper manufacturers on both sides of the border. During the decade 1969-1978, imports of paper and board based on mechanical pulp (primarily newsprint) grew at a rate of $0.7 \%$ per annum, or about $2 \%$ slower than GNP. This growth rate is essentially the same as that for consumption. However, beginning essentially in 1980, major new mechanical pulping capacity - primarily associated with the production of newsprint - began to come online in the USA. In the decade 19691979 mechanical pulping grew at a rate of $0.7 \%$ per annum in the USA;

${ }^{9}$ While some futurists foresee the not-toodistant era of the 'paperless office', where visual display systems and computer storage virtually replace books, newspapers, journaled records, and other paperintensive communications applications, others argue that as information processing is made easier by electronic technology, the demand for printed reports from this information explosion will be greater than ever. Regardless of which scenario ultimately predominates, however, at least two facts are emerging. First, technological advances continue, and are increasing the viability of the 'paperless office' concept. Microcomputers are rapidly decreasing in cost; and fibre optics systems which could bring in as many as 10000 separate channels to the home and office are in the offing. The second factor is that, despite these technological advances, a number of considerations dictate that large-scale adoption of electronic media systems of the kind that reduce absolute paper use may take decades; we may be well into the next century before we see large-scale competition between printing paper and the electronic media.

${ }^{10}$ This new capacity is associated with a new pulping process, thermo-mechanical pulping (TMP) introduced on a large scale in the USA in the mid-1970s. The rate of introduction of TMP facilities will probably not continue to be as rapid as in 1979-1982. However, the implementation of this new process suggests that the role of Canadian newsprint as a fraction of US consumption will decline sharply during the coming decades.

"Roger S. Carlson, 'World pulp and paper consumption outlook', presented to the Food and Agriculture Organization's Advisory Committee on Pulp and Paper, September 1977. from $1979-1982$ it will grow $21 \%$, or almost $7 \%$ per annum. ${ }^{10}$

Major expansion in markets for paper overseas are envisioned in association with economic growth in Europe and the developing countries. Significant worldwide deforestation and increasing literacy are important factors in this market expansion. North American producers should capture some of this market, although much of the market could be filled by East Asian, especially Siberian, woodpulp. The most promising products are linerboard for shipping containers and, to a lesser degree, printing papers. ${ }^{11}$

\section{Conclusions}

We conclude these remarks with a projection for the next two decades. Domestic consumption of paper products (tonnage) will follow its 1970s' pattern, declining about $1 \%$ per annum with respect to real GNP $(1.1 \%$ per annum in Table 3 ). Perhaps the major uncertainty in this projection in the long term is whether printing papers will continue to grow faster than service employment.

Macroeconomic models generally indicate growth in consumption of paper products at roughly $0.7 \%$ per annum faster than real GNP (the difference between the FRB index and physical production). This is presumably because the basic data for macroeconomic models is for 1972 and earlier, the last year for which input-output coefficients are available. Prior to 1973 the consumption of paper products in physical terms closely tracked real GNP.

Relative to our projection, a projection based on macroeconomic models rising $1.8 \%$ per annum faster would be over $40 \%$ higher in 20 years. This kind of discrepancy, extended to other basic materials industries, is the single most important reason for very high estimates for the energy needs of industry at the turn of the century.

Production of paper products, as contrasted with consumption, should decline less rapidly with respect to GNP. By the turn of the century, imports are likely to decline as much as a few million tons per year and exports rise as much as a few million tons per year relative to their 1978 


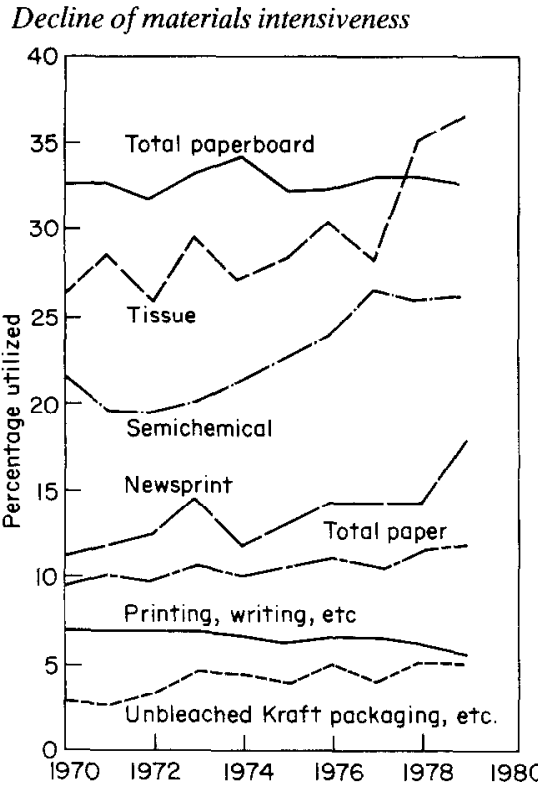

Figure 5. Percentage of paper products made from waste paper.
${ }^{12}$ 'Energy from Biological Processing', Office of Technology Assessment, US Congress, 1980. levels. That is, in each case, the flows could shift towards more US production by a significant fraction of the present flows. Net exports less imports might thus increase as much as $10 \%$ of present production by 2000. This would require an increase in production of about $0.5 \%$ per annum. We predict that production will rise with respect to consumption somewhat more slowly, $0.3 \%$ per annum, or a decline of $0.8 \%$ per annum with respect to GNP. If GNP rises an average of $2.8 \%$ per annum over the next $10-12$ years, our prediction would be $2.0 \%$ per annum growth in paper production.

\section{Virgin fibre resources}

There is a general tone of optimism with regard to future availability of virgin fibre for paper production. Most analyses indicate few problems of supply. A recent major report of the Office of Technology Assessment (OTA $)^{12}$ reflects this optimism. It notes that ' . . the potential of US commercial forests is substantially higher than current output. Achieving this potential, however, will require more intensive forest management'.

l'he key phrase in this observation is intensive forest management. How it is defined in terms of a number of constraints, particularly environmental ones, will determine whether grounds for optimism on fibre availability are realistic.

Increasing the intensiveness of forest management can simply mean improving forest industry productivity or it can mean significant despoiling of virgin timber stands, particularly in the west, and large-scale logging of other relatively untouched forest areas.

The increasingly conservative national political and economic climate would seem to indicate that in the next few years intensive forest management will be interpreted more liberally in environmental terms. This in turn will mean fewer problems in virgin fibre supply in the near future. Perhaps the major threat to the availability of virgin fibre resources for paper production is the possibility of large-scale use of timber for biomass processes. The above-cited OTA report studied this problem in some detail and again came to optimistic conclusions. It even predicted that, once large-scale biomass programmes become developed, they will utilize mostly low quality timber and residue and will impinge oniy minimally on high-grade forest activity:

In time. . . the fuelwood harvests would come mostly from the removal of logging residues, various types of thinnings, and the removal of dead, dying and diseased trees.

The OTA study strongly implies, in fact, that development of biomass processes, with resulting significant increases in fuelwood demand, will mean concerted efforts at improved forest management that will ultimately mean minimizing environmental impacts of logging, and increasing availability of high-quality timber.

It is important to emphasize that there is some conjecture on the subject of future supplies of timber and competition for virgin pulp. A number of economic and policy factors will have significant influences on such supplies. From most reasonable perspectives, however, the supply picture over the next two decades appears relatively bright.

\section{Recycled fibre}

The level of use of recycled fibre, or waste paper, under present 


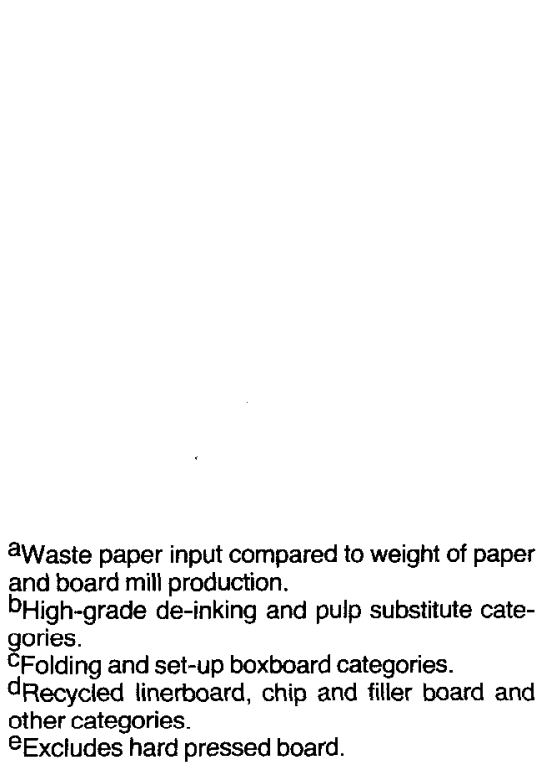

${ }^{13}$ This section relies heavily on William $\mathrm{E}$. Franklin, Paper recycling. The Art of the possible, 1970-1985, Midwest Research Institute, Kansas City, MO, 1973; and Solid Waste Management and the Paper Industry, Franklin Associates, Ltd, and International Research and Technology Corporation, 1979.

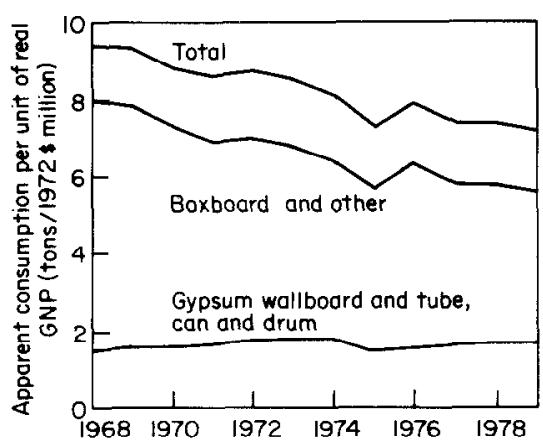

Figure 6. Apparent consumption of boxboard per unit of GNP.
Table 6. The use of waste paper in the manufacture of paper and paperboard, 1977, by final product (millions of tons).

\begin{tabular}{|c|c|c|c|c|c|c|}
\hline & \multirow[b]{2}{*}{$\begin{array}{l}\text { Waste } \\
\text { Paper }\end{array}$} & \multirow[b]{2}{*}{$\% \mathbf{a}$} & \multicolumn{3}{|c|}{ Grade of Waste Paper } & \multirow[b]{2}{*}{ High-grade } \\
\hline & & & Mixed & News & Corrugated & \\
\hline $\begin{array}{l}\text { Paper } \\
\text { newsprint } \\
\text { printing, writing } \\
\text { packaging, industrial } \\
\text { tissue }\end{array}$ & $\begin{array}{l}0.54 \\
0.91 \\
0.22 \\
1.20\end{array}$ & $\begin{array}{r}14.1 \\
6.6 \\
4.0 \\
28.0\end{array}$ & $\begin{array}{l}0.01 \\
0.04 \\
0.10\end{array}$ & $\begin{array}{l}0.54 \\
0.02 \\
0.09\end{array}$ & $\begin{array}{l}0.02 \\
0.12\end{array}$ & $\begin{array}{l}0.90 \\
0.14 \\
0.88\end{array}$ \\
\hline $\begin{array}{l}\text { Container board } \\
\text { unbleached kraft } \\
\text { semichemical corrugating }\end{array}$ & $\begin{array}{r}0.54 \\
1.15\end{array}$ & $\begin{array}{r}4.0 \\
27.1\end{array}$ & 0.02 & & $\begin{array}{l}0.51 \\
1.11\end{array}$ & $\begin{array}{l}0.02 \\
0.04\end{array}$ \\
\hline $\begin{array}{l}\text { Recycled paperboard } \\
\text { recycled medium } \\
\text { gypsum linerboard } \\
\text { recycled tube } \\
\text { recycled boxboardc } \\
\text { others } d\end{array}$ & $\begin{array}{l}0.81 \\
1.13 \\
0.90 \\
3.06 \\
2.02\end{array}$ & $\begin{array}{r}75.3 \\
107.3 \\
108.4 \\
114.7 \\
120.0\end{array}$ & $\begin{array}{l}0.02 \\
0.25 \\
0.15 \\
0.87 \\
0.33\end{array}$ & $\begin{array}{l}0.25 \\
0.16 \\
0.69 \\
0.22\end{array}$ & $\begin{array}{l}0.80 \\
0.48 \\
0.50 \\
0.99 \\
1.30\end{array}$ & $\begin{array}{l}0.16 \\
0.10 \\
0.53 \\
0.16\end{array}$ \\
\hline $\begin{array}{l}\text { Construction paper } \\
\text { and boarde }\end{array}$ & 1.80 & 54.7 & 0.97 & 0.32 & 0.38 & 0.12 \\
\hline Total & 14.29 & & 2.77 & 2.29 & 6.21 & 3.02 \\
\hline
\end{tabular}

conditions is largely a question of demand. ${ }^{13}$ The potential supply of all but top grades of waste substantially exceeds demand. The principal grades of waste paper considered here are:

- mixed (primarily post-consumer waste printing papers from offices);

- news (primarily post-consumer newspapers);

- corrugated containers (primarily corrugated shipping containers recycled from retail stores);

- high-grade de-inking papers and pulp substitute (primarily prompt scrap from paper converting and printing plants).

Present levels of use of waste paper are primarily by the paper industry (14.3 million tons in 1977), but also for export (1.5 million tons) and for non-paper products such as insulation, stuffing for padded envelopes and dunnage ( 0.6 million tons).

The use of waste paper as a feedstock for various paper products is shown in Table 6 . The major use is in recycled paperboard, a broad category, almost entirely made from waste paper, absorbing about $55 \%$ of recycled paper (see Appendix). Other major uses are in newsprint, writing and printing papers, tissue, corrugating medium for shipping containers, and construction paper and board (primarily insulating board and roofing felts). We shall now discuss trends in use of waste paper in those products shown in Figure 5 and trends in production of these products.

Domestic production of newsprint is moving forward vigorously at present, even if consumption is not. The fraction of recycled news to make newsprint (both in new 100\% recycled newsprint mills and mixed recycled and virgin fibre newsprint) is increasing. Such use of waste paper was $11 \%$ (as a fraction of production) in 1970 and $14 \%$ in 1977 . Newsprint manufactured from recycled newspapers has higher tear strength, although it has lower burst strength.

The market for printing and writing papers is keeping pace with GNP. Waste paper of high quality retains a small and steady part in the fibre input, much of it for specialty papers. The high-grade wastes are primarily manufacturers' wastes, almost all of which are recycled into appropriate products. 
aAdapted from William E. Franklin, Paper Recycling. The Art of the Possible 1970-1985, Midwest Research Institute, 1973, Chapter 5, Tables 16 and 19.

bpulp substitute and high-grade de-inking wastes. As much as one third of de-inking stock comes from bleached paperboard and other operations. For convenience, de-inking stock is compared with printing, writing, etc, production

CThis data is for consumption of waste paper by the domestic paper industry. Another 0.5 million tons were used by other industries or in exports for a total recovery rate of $21.8 \%$.

dSimply post-consumer recovery compared to apparent supply less converting plant recovery.

epaper packaging, tissue, boxboard, construction and board.

afrom American Paper Institute, Statistics of Paper and Paperboard, 1979, pp 4 and 21.

bpulp substitute and high-grade de-inking wastes. As much as one third of de inking stock comes from bleached paperboard and other operations. For convenience de-inking stock is compared with printing, writing, etc, production.

CFrom American Paper Institute, Paper, Paperboard, Woodpulp Capacity, 1977-1980, p 22.

$\mathrm{d}_{\mathrm{O}}$ this, 14.3 million tons was used by the domestic paper industry and the rest by other industries or exported. The $24.4 \%$ recovery rate is to be compared with $21.8 \%$ in 1970 ; see note $c$ to Table 7 .
The use of recycled fibre in tissues is relatively high and the percentage is slowly increasing. The market for tissues is growing somewhat more slowly than GNP.

The production of corrugated shipping containers is roughly keeping pace with GNP. Waste paper is a small input among all fibre in the manufacture of unbleached kraft linerboard used in containers, but the percentage is growing and is projected by Franklin Associates to continue growing rapidly. Moreover, waste paper is a significant input for making the corrugating material, and the percentage has been slowly increasing, displacing semichemical pulp.

Recycled paperboard is a broad category of products made almost entirely of recycled fibre, so the issue here is solely the demand for different types of recycled board. Sales of several products are roughly keeping pace with GNP growth, the most important products being: recycled medium (for corrugation); gypsum linerboard (the liner material for gypsum wallboard); and tubes, cans and drums based on recycled fibre (Figure 6). Production of paperboard mills going into these products was about 3 million tons in 1977. Sales of other recycled paperboard products have been declining absolutely, ie declining several percent per annum with respect to GNP: boxboard (eg for retail boxes for cereals and washing powder), chip and filler board, and other recycled board with total production of over 4 million tons in 1977. The problems these products encounter in competition with plastics was discussed above.

One aspect of the demand problem facing recycling of paper is clear; the largest product category which utilizes waste paper suffers from a weak market. Other products which offer the potential of growth in waste paper recycling, such as newsprint, tissue and shipping containers, are limited by product growth and by the percentages of waste paper inputs presently considered acceptable. Of great importance is the possibility that innovative manufacturers may be able to produce acceptable

\begin{tabular}{|c|c|c|c|c|c|c|}
\hline & \multirow[b]{2}{*}{$\begin{array}{l}\text { Apparent } \\
\text { supply }\end{array}$} & \multirow[b]{2}{*}{$\begin{array}{l}\text { Waste } \\
\text { paper } \\
\text { grade }\end{array}$} & \multicolumn{3}{|c|}{ Waste paper recoveryc } & \multirow[b]{2}{*}{$\begin{array}{l}\text { Post-consumer } \\
\text { recovery rate }(\%)^{0}\end{array}$} \\
\hline & & & $\begin{array}{l}\text { Converting } \\
\text { plants }\end{array}$ & $\begin{array}{l}\text { Post- } \\
\text { consumer }\end{array}$ & $\begin{array}{l}\text { Recovery } \\
\text { rate }(\%)^{c}\end{array}$ & \\
\hline Newsprint & 9.8 & news & 0.02 & 2.21 & 23 & 23 \\
\hline Printing, writing, etc & 11.2 & $\begin{array}{l}\text { mixed } \\
\text { high-grade }\end{array}$ & $\begin{array}{l}0.77 \\
2.41 \mathrm{~b}\end{array}$ & $\begin{array}{l}1.87 \\
0.66\end{array}$ & 20 & 32 \\
\hline Container board & 13.3 & $\begin{array}{l}\text { corrugated } \\
\text { containers }\end{array}$ & 1.50 & 2.58 & 31 & 22 \\
\hline Othere & 23.5 & none & smallb & small & $\sim 0$ & $\sim 0$ \\
\hline All paper and board & 57.8 & all grades & 4.7 & 7.3 & 20.8 & 14 \\
\hline
\end{tabular}

\begin{tabular}{lllll}
\hline Table 8. Sources of recycled fibre and recovery rates, 1977 (millions of tons). & \\
\hline & $\begin{array}{l}\text { Apparent } \\
\text { supplya }\end{array}$ & $\begin{array}{l}\text { Waste paper } \\
\text { grade }\end{array}$ & $\begin{array}{l}\text { Waste paper } \\
\text { recoveryc }\end{array}$ & $\begin{array}{l}\text { Recovery } \\
\text { rate (\%) }\end{array}$ \\
Newspaper & 11.2 & news & 3.08 & 28 \\
Printing, writing, etc & 13.9 & mixed & 3.17 & 23 \\
high-grade & $3.27^{\mathrm{b}}$ & \\
Containerboard & 10.9 & corrugated container 6.83 & 40 \\
Other & 25.9 & none & smallb & -0 \\
All paper and board & 66.9 & all grades & $16.4^{\mathrm{d}}$ & $24.4^{\mathrm{d}}$ \\
\hline
\end{tabular}


products with much higher inputs of post-consumer waste, as is happening with newsprint.

The long-term supply of post-consumer waste is, in terms of domestic paper industry requirements, ample. Table 7 and Table 8 show the sources, quantities and recovery fractions of the major grades of waste paper in 1970 and 1977 . The recovery rate (penultimate column of Table 7 and final column of Table 8) grew from $21.8 \%$ in 1970 to $24.4 \%$ in 1977. Substantial growth during this period occurred in recovery of corrugated shipping containers and in recovery of newspapers. The breakdown and baling of used shipping containers by major retail outlets became widespread during the 1970s. Dependable markets for used newsprint were established in this period by Garden State Paper and its affiliates in regions of roughly 200-miles radius centred at their plants in New Jersey, Georgia and Southern California. Recovery of printing and writing papers was roughly unchanged for the period. Market mechanisms leading to more effective separation of wastes by grade at offices would substantially increase the supply of these high-grade wastes. In all sectors it seems likely that major increases in the recovery rates could occur. In his 1973 study, Franklin estimated maximum recovery rates of $40-50 \%$ for newsprint, $35-45 \%$ for mixed waste from printing and writing papers and $45-55 \%$ for corrugated containers (these rates are for paper used in metropolitan areas). Increases in the recovery rates up to these levels might occur simply from establishment of assured markets at moderate, but stable, prices. The instability of the markets for post-consumer waste paper has seriously hindered establishment of high recovery rates. Somewhat higher recovery rates than estimated by Franklin could in principle be achieved if the general climate for recovery were different, as indicated by wartime experience and experimental community programmes.

\section{Regulation and policy}

Several regulation and policy considerations could have significant influence over the flow of both virgin and recycled fibre and the mix between them in total paper production and use. They fall into three categories which we shall call supply, recycling, and market. The first group, supply, connotes those policy and regulation factors which may have substantial impacts on the availability of fibre for pulping. Recycling covers those factors that will be instrumental in determining the mix of virgin and secondary fibre use. Market, the third category, includes areas where policy and regulation activities may be influential in determining how paper fares with competitive materials or alternative, non-materialsintensive, systems. ${ }^{14}$ Among the more prominent factors are:

${ }^{14}$ Arthur H. Purcell, The Waste Watchers, Doubleday/Anchor Press, New York, 1980.

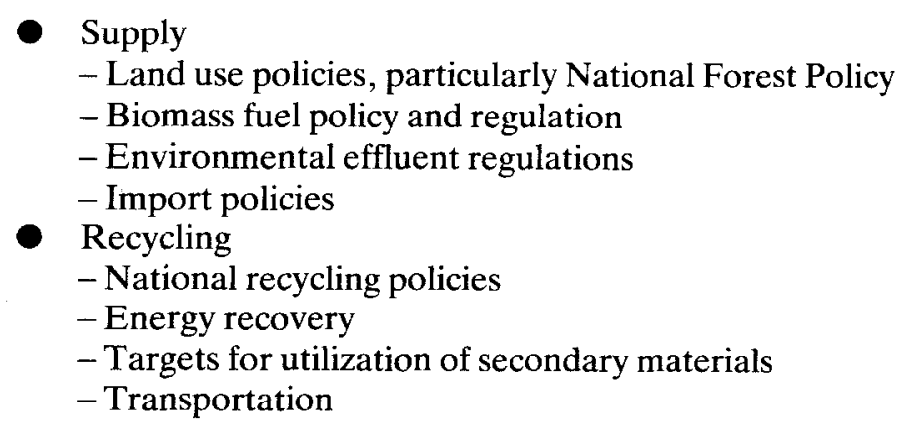


- Government procurement

- Product charges/recycling tax incentives

- Market

- Packaging regulations

- Communications policy

- Export policies

Supply

Land use policies. Land use policies over the next twenty years will influence the supply of virgin fibre to the paper industry. This in turn will affect, first, the degree of paper recycling practiced and, second, probably to a lesser extent, the possibility of pulp supply limitations.

Clearly, the greater the supply of virgin fibre - and hence the lower the cost - the less incentive there is to utilize more recycled fibre. Policies leading to the opening up of National Forests to increased logging will enhance virgin supply; the new Alaska lands bill, for example, allows for such increases. In the next few years pressure for opening up more national lands to timbering will increase. On the other hand, it is conceivable that we may see a near reversal of currently projected land use trends. Through limiting or curtailing access of federal lands to the forest industries, a positive influence on pulp recycling and conceivably even shortages of virgin fibre could occur. This latter trend appears, however, most unlikely.

Biomass fuel policy and regulation. Tied to land use questions of forest management is the still amorphous, and potentially very significant, area of biomass fuel production. Options ranging from utilizing current forests for alcohol production to mandated planting of biomass crops on land suitable for forests all have significant impingement potential on future pulp supplies. At present it is difficult to determine whether this potential will be of any consequence in the near future.

Environmental regulations. As with other materials producing industries, the paper industry has to comply with a number of strict effluent regulations - chiefly in the water pollution area. When strong federal regulations were first promulgated over a decade ago, significant concern was expressed in many quarters that a number of paper mills would be forced to shut down, with inflated paper prices and even shortages resulting. This did not turn out to be the case. As paper industries faced cleanup tasks, so did their non-paper competitors. It is not overly naive to observe that pollution control costs have tended to cancel each other out. Paper was not put at a disadvantage, nor did it gain any particular advantage from increased environmental regulation. Indications are that this phenomenon will continue, despite the possibility of relatively stricter and more costly regulation of the so-called toxic chemical industries encompassing plastics.

Import policies. Increased importation of fibre or pulp would obviously increase total supplies while reducing the domestic (but not total) energy content of fibre and pulp. At present the USA does import both finished paper (primarily newsprint) and some pulp. No dramatic import policy changes which willl significantly affect a standard projection of paper importing are anticipated. 
National recycling policies. ${ }^{15}$ It is generally agreed that national policy and regulation will have a clear impact on the mix of recycled and virgin materials utilized over the next two decades. A very fundamental question which must be answered before paper recycling policy is fixed, however, is: what constitutes 'rccycling'? Re-use of secondary paper fibre in repulping operations, or recovery of the energy content of paper through thermal destruction of the fibre?

Energy recovery. Present indications are that the latter definition of recycling prevails at the federal level. The Department of Energy (DOE), now the only federal agency substantially involved in recycling work, has recently promulgated a price support programme to encourage energy recovery from municipal wastes, with paper the prime component of these wastes. The proposed programme has resulted in a law suit brought by the American Paper Institute, which charged that the DOE proposal discriminates against fibre recovery of paper.

Proponents of this scheme argue that economics will dictate that higher-grade papers, worth separating on a source separation basis, will still be worth more to pulping mills than to energy recovery systems if this programme is adopted. Only the so-called lower-grade papers and those irretrievably contaminated will be subjected to energy recovery.

It is not evident whether a large-scale energy recovery programme will inhibit recycling of paper fibre; clearly, however, it will not abet it. Strong national policies will have to prevail, however, if the situation that has arisen in Akron, Ohio, is to be prevented. There, scavenging of wastes, traditionally the only viable method of collecting source separated recyclables, has been prohibited; the rationale is to ensure that the supply of combustibles for Akron's new waste-to-energy plant is not diminished. This flow control ordinance has been appealed against and, ultimately, will probably be held invalid. Regulations of this type, however, are clear inhibitors to recycling the material content of paper.

Secondary materials. A contradictory area of regulatory effort is the setting of targets for minimum utilization of secondary fibres. In the Energy Policy and Conservation Act of 1976 and the National Energy Conservation Policy Act of 1978, Congress called on the Department of Energy to set standards for the minimum content of certain recycled materials to be used in a variety of products. The DOE, in response to industry concern with the rigidity of standards, has not tried to ambitiously force recycling of waste paper by this mechanism.

Transport. One perpetual source of annoyance to recyclers has been the discrimination against secondary materials practiced by the Federal Interstate Commerce Commission. The heterogeneity of secondary materials vis à vis virgin materials, and thus the additional costs of loading and storage, is the basis for discrimination. There is little agreement, however, on how to minimize the discrimination; in addition, economists do not agree whether discriminatory freight rates are significantly inhibiting recycling. In January 1981, the US Supreme Court unanimously

${ }^{15}$ Resource Conservation Committee, Choices for Conservation, US Environmental Protection Agency, Cincinnati, $\mathrm{OH}, 1979$. supported the concept of discriminatory freight rates in reversing a ruling that had blocked Conrail from charging higher shipping rates for products made from recycled material than from virgin material. The freight rate 
situation is an illustrative example of the incoherence of a national 'recycling' policy. Paper and all other recyclable materials will continue to be affected by this incoherence.

Government procurement. Another federal policy area of potential significance to recycling, particularly paper recycling, is that of procurement policy. The federal government is a huge buyer of paper. Several laws and regulations, including the Resource Conservation and Recovery Act, allude to the need for federal procurement policy to be oriented toward purchase of goods made with secondary materials. To date, however, the impact of federal procurement policies on recycling is still small. Over the next two decades, however, it is probable that this impact will increase and thus have a significant and positive effect on the mix of recycled fibres used in paper production.

Product charges/recycling tax incentives. The cabinet-level Resource Conservation Committee established in the Carter Administration spent considerable effort looking into the feasibility of so-called 'product charges', ${ }^{16}$ In a product charge system, goods are taxed according to the amount of secondary materials they are composed of. Thus a product made of all virgin materials would be taxed at the maximum amount (a few cents per kilogram), while one made from all recyclables would be tax-exempt. Revenues from the tax would be used to develop recycling capabilities. The Committee, which never achieved the influence intended when it was set up under the Resource Conservation and Recovery Act, did not endorse a national product charge system. Its study, however, represented the first serious federal look into this system. In future it is possible that some form of product charge system will be instituted; this could serve only to enhance the recycling share of the total materials mix.

\section{Market}

Packaging regulations. Since well over $50 \%$ of total paper and board production is used for packaging, regulations directed toward packaging will have significant impacts on paper. Most proposed packaging regulations are geared toward environmental and resource considerations. They tend to favour paper over plastics; the rationale is that plastics are derived from a non-renewable energy source while paper comes from a renewable resource. Concern over migration of toxic chemicals in plastics into the food they package and non-biodegradability of most plastics are other factors that tend to favour paper over plastics. At present there are very few packaging regulations in place, the chief existing regulations being in Minnesota. In 1976 the Minnesota legislature enacted a so-called 'packaging statute'. This law gives power to 'review' new packaging forms entering the state in terms of potential resource and environmental impacts. The statute was challenged immediately in court and enjoined from going into effect for nearly three years. After several legal battles Minnesota's packaging statute has been upheld. To date it is too early to tell what effect, if any, the law will have on the material composition of packaging in the Minnesota market.

Over the next two decades, however, the statute will undoubtedly have an impact. If other states adopt similar measures the effects will be felt on a national scale. All the indications are that paper would benefit over plastics, its main packaging competitor. 
In a separate action in Minnesota, plastic milk cartons have come under regulatory attack. Consumer demand has favoured lightweight paper and plastic milk containers over heavier glass ones. Walls of plastic containers have become thinner and paper per container has been reduced as plastics and paper compete. The state of Minnesota banned the sale of milk in plastic cartons in the 1970s for their perceived environmental wastefulness and possible health impacts. This ban was challenged all the way to the US Supreme Court and upheld. In a January 1981 decision, which could have far reaching impacts on materials flows, the Court said the Minnesota legislature had a rational basis - prevention of pollution for its law and that was all that was necessary.

Again, the possibility of this type of law going into effect in other states points to a gain in paper use for packaging. Some observers do not, however, believe that the Minnesota precedent bodes particularly well for paper. As one paper industry analyst has noted, 'If they can do it to plastics, they can do it to paper. In the longer term we could actually be worse off'.

Communications policy. Most regulatory and policy considerations germaine to this study are projected to affect the supply of materials or the market share of paper in competition with other materials. In one area of consideration, however, the issue is whether paper will be supplanted by alternative systems which are not materials-intensive. This is the area of communications. As discussed above, the advent of the 'paperless office' could pose serious challenges to growth in the paper industry. The rate at which electronic displays and computer storage begin to compete with the printed word will be strongly dependent on actions such as deregulation of the communications industry. As the trend to deregulation continues, it will be easier for new technologies such as fibre optics systems - to proliferate to office and household levels. As this occurs, traditional mainstays of the paper market telephone books, newspapers, etc - will be strongly challenged by instantly erasable and storable display systems.

Export policy. Greatly increasing literate populations, combined with gross deforestation in a good fraction of the world's populated areas, will mean a growing export market for paper over the next twenty years. No dramatic US export policy is anticipated which will inhibit the flow of US paper or pulp and fibre abroad.

\section{Concluding remarks}

Our analysis lends credence to the concept that as productivity increases, materials (in this case paper) intensiveness decreases; ie less materials are being used to perform the functions which consumers demand. Forecasts based on macroeconomic models have generally failed to delineate this important trend. There are two principal reasons for this:

- The models are based primarily on pre-1973 data from an era of cheap energy and materials.

- Economic measures used in models, such as Federal Reserve Board Indices, may grow faster than production measured in physical terms. 
As a result macroeconomic growth projections can be, perhaps, $2.0 \%$ per annum higher than actual performance. Resource planning using such projection is thus likely to be dramatically in error over a period of time such as 20 years.

For paper, a major factor in decline of materials intensiveness is the maturity of paper products. With the exception of one important class of paper products - printing papers - all major categories of paper products have matured; ie consumption is no longer growing faster than obvious indicators of the consuming activity.

\section{Appendix}

\section{A. Paper products}

Newsprint. Newsprint is used for newspapers. Made mainly from mechanically ground pulp, it also contains about $10 \%$ chemical pulp. Because the paper has a high lignin content (the substance that binds the fibres together in the tree), it turns yellow and brittle in a relatively short time.

Printing papers. Uncoated groundwood, book and coated papers are often grouped together as printing papers. Uncoated groundwood papers contain groundwood and chemical pulps, as does newsprint, but there the similarity ends. The groundwood grades contain less groundwood and more chemical pulps than newsprint; the pulps are frequently bleached, whereas newsprint generally uses unbleached pulp, and are of a higher quality than those used in newsprint. In addition, the sheets are frequently surface treated (eg sizcd, supcrcalendered, or clay filled). Coated papers are used largely in magazines. Paper coated on only one side is used for can labels. Book papers go in books, magazines and pamphlets, and are used in commercial printing as well as in business stationery and enevelopes.

Fine papers. These were grouped with printing papers in this report. Some grades are made largely from cotton fibre and found in the more expensive writing papers and enve- lopes, stock and bond certificates, and money. Most fine papers, however, are made from chemical wood pulp. Business and industry uses fine papers for cheques, writing paper, ledger and mimeograph papers, maps and charts, and blueprints and other sensitized papers. Many greeting cards are also made from this grade of paper.

Coarse packaging papers. These are the heavy-duty packaging papers used to wrap and package products. Grocery bags and sacks, and gaily coloured notion and specialty bags, are all made from coarse papers, as are paper shipping sacks, such as those used for cement, sugar and flour. Coarse papers may be converted into a great many special products, including envelopes, gumming paper, asphalting paper, and coin wraps.

Special industrial papers. These were grouped with packaging papers in this report and are made for industrial uses. A few of the more important types include: abrasive paper, electrical insulation paper, gasket paper, tabulating card stock, filter papers and absorbent papers.

Sanitary and other tissue papers. Major uses include paper towels, toilet tissue, paper napkins and paper handkerchiefs.

\section{B. Paperboard products}

Containerboard. This is the largest single grade of paper made. There are two major types: linerboard and corrugating material. Liner and corruga- ting materials are made into paper board corrugated shipping containers, also called fibre boxes. Corrugating material was once made largely from straw, but today is made mainly from hardwood pulp.

Folding boxboard. Most of the cartons holding dry cereals, toothpaste, soap powders and other common household products are made from folding boxboard. Mainly made from waste paper, the outer surface of this board is usually designed to take a fine printing, while the inner part gives the bulk, rigidity and protection necessary for a carton.

Special food board. This is a type of boxboard made from bleached chemical pulp. It is used to package moist and oily foods. Milk cartons, frozen food packages, ice cream cartons, and paper plates are made from this type of board.

Set-up boxboard. Made mainly from waste paper, it is much thicker than folding boxboard. Shoe boxes, sweet boxes and jewellery boxes are common products.

Other paperboard. In this group are such boards as fibre can, tube and drum stock, liners for the gypsum board that may be used as walls in the home, and cardboard.

Construction. Grades include roofing, floor covering, automotive felts and insulating board.

Source: Various American Paper Institute documents. 